\title{
Respiratory Rates of Inga Vera Willd. Subsp. Affinis (DC.) T. D. Penn. Seeds
}

\author{
João José Dias Parisi ${ }^{1}$ (D), João Domingos Biagi² ${ }^{\circledR}$, Claudio Jose Barbedo ${ }^{3}$ (i), \\ Priscila Fratin Medina ${ }^{4}$ (D), Edmir Vicente Lamarca ${ }^{5}$ (D) \\ ${ }^{1}$ Instituto Florestal, Estação Experimental de Tupi, (IF/EET), Piracicaba, SP, Brasil \\ ${ }^{2}$ Universidade Estadual de Campinas (Unicamp), Campinas, SP, Brasil \\ ${ }^{3}$ Instituto de Botânica (IBt), São Paulo, SP, Brasil \\ ${ }^{4}$ Instituto Agronômico (IAC), Campinas, SP, Brasil \\ ${ }^{5}$ Universidade Ibirapuera (Unib), São Paulo, SP, Brasil
}

\begin{abstract}
The deterioration process of recalcitrant seeds is not fully known, mainly regarding the relation between fungi activity and respiration. Inga vera seeds are characterized by their high degree of sensitivity to desiccation and for only maintaining viability for a few weeks. The objective of this study was to identify the fungus action on respiratory metabolism of $I$. vera embryos subjected to chemical treatment in order to extend their storability. The results showed that the presence of fungi increases embryo respiration rate, thus affecting their conservation during storage. Treatment with carbendazin + thiram, especially at a dose of $200 \mathrm{ml}$ per each $100 \mathrm{~kg}$ of seeds, was effective in controlling fungi, reducing the respiration rate and metabolism of $I$. vera embryos, increasing the maintenance period of their viability in storage.
\end{abstract}

Keywords: fungus, recalcitrant seed, storage. 


\section{INTRODUCTION}

The growing demand for seeds of forest species for various purposes of use has a lack of information about quality, especially from the health point of view (Santos et al., 2011; Vechiato \& Parisi, 2013). In Brazil, studies on forest seed health began in the 1970s, mainly for species classified as orthodox, but only in recent years research has been intensified on pathogenicity, transmission, damage caused by pathogens and the control of these. However, the absence of information on biochemical and cellular transformations occurring during storage make it difficult to understand the deterioration process resulting from fungus activity, especially in seeds susceptible to dehydration, initially denominated recalcitrant by Roberts (1973).

Inga vera Willd. subsp. Affinis (DC.) T.D. Pennington is a species from the Atlantic Forest that presents seeds with characteristic recalcitrant behavior, represented by the high degree of sensitivity to desiccation and its conservation of viability for only a few months. As they cannot be subjected to drying, recalcitrant seeds are dispersed with intense metabolic activity, do not demonstrate cellular dedifferentiation, and consequently can only be conserved until germination or rapid deterioration begins (Barbedo et al., 2013; Pammenter \& Berjak, 2014).

The best conditions for seed storage to minimize the deterioration process are those that promote reduced metabolic activity, with reflexes on the embryo's respiration levels (Carvalho \& Nakagawa, 2000). This process depends on and can be modified by water and thermal variations, as verified by Lamarca \& Barbedo (2012) in Caesalpinia echinata L. seeds, so that the reduction in temperature and water content of the seeds are the main resources for reducing metabolic activity.

Reducing the temperature to levels that do not freeze tissues reduces metabolism, which decreases the respiratory rates of I. vera embryos and increases its storage potential, but this procedure also induces a manifestation of unidentified oxidative reactions (Bonjovani \& Barbedo, 2014). Such storage conditions can still lead to embryo deterioration, both due to the metabolism itself and the growth of microorganisms favored by its high degree of humidity. The intense respiratory activity of the embryos, added to the activities of microorganisms, can cause the mass to warm up, further accelerating the deterioration process (Carneiro \& Aguiar, 1993).

The occurrence of storage fungi in recalcitrant stored seeds is one of the main detrimental factors to preserving viability (Berjak, 1995). However, the ones considered as "field fungi" have also been simultaneously detected in Inga vera embryos with deterioration progression during storage (Parisi et al., 2013). Fungi can become a major problem, even in cryopreservation of embryos or embryonic axes, which is currently the only way to preserve species with recalcitrant seeds in germplasm banks (Berjak et al., 2014; Walters et al., 2013)

The presence of fungi can increase the respiratory rates of the embryo-fungi complex, intensifying the embryos metabolism, thus affecting viability preservation. Deepening this knowledge will enable developing technologies which will increase the conservation period of forest seeds, resulting in greater availability of high-quality seeds and seedlings. Thus, the objectives of this work were to identify the fungal action on the respiratory metabolism of I. vera embryos and to verify the effectiveness of chemical treatment, aiming to maintain the viability time of these embryos during storage.

\section{MATERIAL AND METHODS}

\subsection{Plant material}

Ripe yellow Inga vera subsp. Affinis (Penn.) fruits were collected from marked branches of 30 matrix trees in parks and around the Piracicaba river in the municipality of Piracicaba, São Paulo (SP) (47038'00" W, 22 $2^{\circ} 42^{\prime} 30^{\prime \prime}$ S, $546 \mathrm{~m}$ altitude), in 2010 and 2011. The color of their skins/peels at the time of harvesting was classified as Yellowish (7,8 GY 8/10), according to Munsell Color (1952).

The fruits were manually opened in the laboratory to extract the seeds, not exceeding 24 hours after harvesting, and discarding those that presented damage by insects. The sarcotesta (teguments) were subsequently removed, and the embryos were stored in plastic bags in a BOD (Biological Oxygen Demand) chamber set at a constant temperature of $7^{\circ} \mathrm{C}$, without light until the beginning of the experiments, not exceeding seven days from harvesting. 


\subsection{Seeds physical, physiological and health evaluations}

Embryos were evaluated for water content, germination, health and respiratory rates. The water content was determined by a forced air circulation oven at $103{ }^{\circ} \mathrm{C}$ for 17 hours (Brasil, 2009), with four replicates of five embryos. The results were expressed as percentage on wet basis.

The germination tests were conducted in germinators with a water curtain on the posterior wall with continuous light at $25^{\circ} \mathrm{C}$, using a paper roll with two sheets for the base and one for the cover. Normal seedlings were evaluated every two days until the $21^{\text {st }}$ day after installation and the results expressed as a percentage, as described by Bonjovani \& Barbedo (2008). Four replicates of ten embryos were used.

The health tests were performed according to the filter paper method (Parisi \& Santos, 2011), and five embryos, equidistant from each other, were plated in 9-cm-diameter Petri dishes containing three sheets of filter paper, moistened with distilled water and maintained for seven days at $20^{\circ} \mathrm{C} \pm 2{ }^{\circ} \mathrm{C}$ under a 12-hour photoperiod. The evaluation of fungal structures in the embryos was performed under stereoscopic microscope and under optical microscopy in case of doubts. Each replicate was formed by two Petri dishes using four replicates.

\subsection{Fungicidal treatment and respiration at different storage temperatures}

I. vera embryos were divided into two groups in each year of production, one of which was treated with fungicide carbendazin + thiram at a dose of $80 \mathrm{ml}$ for $100 \mathrm{~kg}$ of embryos for those harvested in 2010, and $200 \mathrm{ml}$ for $100 \mathrm{~kg}$ for those harvested in 2011. The carbendazin-thiram blend has been successfully used to control fungi in Brazilian species of Eugenia spp. and Inga vera seeds (Oliveira et al., 2011; Parisi et al., 2013).

An analysis of respiratory rates of 100 embryos was performed by incubating them in four $600 \mathrm{ml}$ hermetically sealed glass vials, each vial being a replication, following the methodology described by Lamarca \& Barbedo (2012). The water content, germination and health were determined before introducing the embryos into the flasks and at the end of the experiment, according to the previously described methodologies.

The lids were perforated and the holes were sealed by a rubber septum to collect air sample from the vial, which was measured in an Illinois 6,600 gas analyzer (Illinois Instruments, Inc., Johnsburg, USA). The total volume of air was considered as the volume of the vial subtracted from that of the incubated embryos. Closure of the flasks was considered as the beginning of the incubation period $\left(\mathrm{t}_{0}\right)$, corresponding to the normal atmosphere (21\% oxygen and $0.03 \%$ carbon dioxide).

Respiratory rates were analyzed by incubating the embryos at temperatures of $7^{\circ} \mathrm{C}$ and $25^{\circ} \mathrm{C}$. Based on previous tests (data not shown), the $\mathrm{O}_{2}$ consumption and $\mathrm{CO}_{2}$ release assessments of Inga Vera embryos were carried out every five days until completing 15 and 25 days, in 2010 and 2011 respectively for those incubated at $7{ }^{\circ} \mathrm{C}$; and daily until completing four and seven days, in 2010 and 2011, respectively, for those incubated at $25^{\circ} \mathrm{C}$. The difference in the evaluation periods is due to the fact that the respiration of Inga Vera embryos at low temperature requires several days for some change in the concentration of gases inside the bottles. The $\mathrm{O}_{2}$ consumption and the release of $\mathrm{CO}_{2}$ are so intense at room temperature that only a few days are sufficient for large changes in these concentrations. This was also verified for seeds from other Leguminosae species, such as Caesalpinia echinata Lam. (Araujo \& Barbedo, 2017; Lamarca \& Barbedo, 2012) and Libidibia ferrea (Mart. exTul.) L.P. Queiroz (Bragante et al., 2018).

$\mathrm{O}_{2}$ consumption and $\mathrm{CO}_{2}$ production by the embryos inside the vials were estimated by the difference between the values measured in the period $\mathrm{n}$ and the initial values $\left(\mathrm{t}_{0}\right)$. The values obtained for $\mathrm{O}_{2}$ and $\mathrm{CO}_{2}$ (in percentage volume) were converted to micromoles using the local atmospheric pressure of $0.90 \mathrm{~atm}$ and calculations described in Lamarca \& Barbedo (2012). These values were divided by the total dry mass of the embryo sample and by the number of days in which they remained incubated, obtaining values in micromoles per gram of dry mass per day $\left(\mu \mathrm{mol}_{\text {.gDM }} \cdot \mathrm{d}^{-1}\right)$. The values obtained for $\mathrm{O}_{2}$ and $\mathrm{CO}_{2}$ were also presented in $\mu \mathrm{mol} . \mathrm{gDM}^{-1} \cdot \mathrm{d}^{-1}$ for a period evaluated at $25^{\circ} \mathrm{C}$ in $2010(24,48,72$ and 96 hours) and in 2011 (24, 48, 120, 144 and 168 hours). 
The respiratory quotient (RQ) was calculated by the Equation 1 described by Kader \& Saltveit (2002):

$$
\mathrm{RQ}=\mathrm{CO}_{2} \cdot \mathrm{O}_{2}^{-1}
$$

The results were submitted to analysis of variance at the $5 \%$ probability level through the Sisvar program (Ferreira, 2011), and when necessary the data were transformed to $\log (\mathrm{x})$ and $(\mathrm{x}+0,5)^{0,5}$ to correct normality and heterogeneity (Santana \& Ranal, 2004).

\section{RESULTS AND DISCUSSION}

The average water content of the $I$. vera embryos collected in January 2010 was $60 \% \pm 0.2 \%$, while those of 2011 had $60 \% \pm 0.6 \%$. Therefore, there was no major difference in the maturation stage of the embryos of the different years (Barbedo et al., 2013).
The respiratory rates of the embryos in both years, treated or not with the fungicide, were higher at $25^{\circ} \mathrm{C}$ than those submitted to the temperature of $7^{\circ} \mathrm{C}$ (Figures $1 \mathrm{~A}$ and $B$ and $3 \mathrm{~A}$ and B). For example, in one day in 2010, embryos incubated at $7{ }^{\circ} \mathrm{C}$ released on average only 1/4 (ca. $25 \mu \mathrm{mol}_{\text {.gDM }}{ }^{-1}$ ) of the $\mathrm{CO}_{2}$ released by those incubated at $25^{\circ} \mathrm{C}\left(\mathrm{ca} .100 \mu \mathrm{mol} . \mathrm{gDM}^{-1}\right)$ over the same period (Figures 1A and B). In 2011 (Figures $3 \mathrm{~A}$ and B), embryo respiration rates were much higher than in 2010 at both temperatures. However, the difference between temperatures was maintained, and the embryos incubated at $7^{\circ} \mathrm{C}$ released on average $1 / 6$ per day ( $c a .50 \mu \mathrm{mol}_{\mathrm{gDM}}^{-1}$ ) of the $\mathrm{CO}_{2}$ released by those incubated at $25^{\circ} \mathrm{C}\left(\mathrm{ca} .300 \mu \mathrm{mol}_{\mathrm{gDM}}{ }^{-1}\right)$. The decrease in temperature causes lower respiration as a result of the reduced metabolism, thus being more favorable for the embryo conservation of this species (Andréo et al., 2006; Bonjovani \& Barbedo, 2008; Faria, 2006).
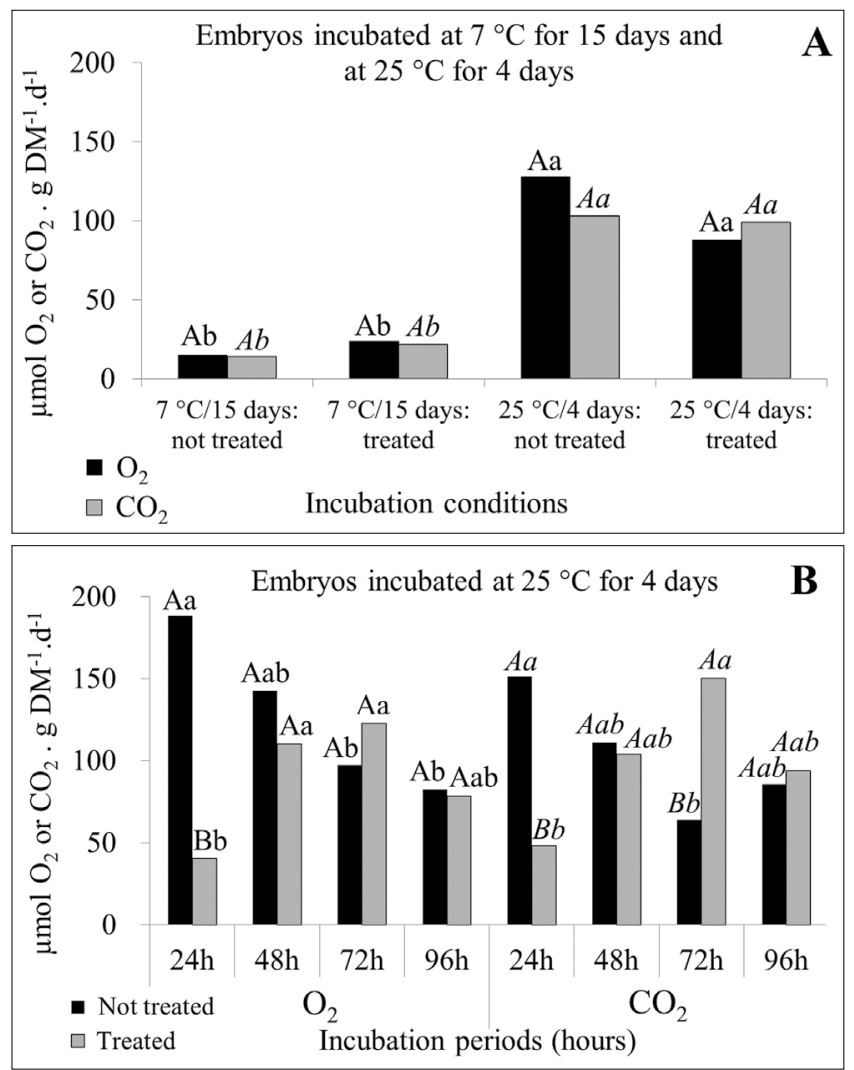

Figure 1. Average daily $\mathrm{O}_{2}$ consumption and average daily $\mathrm{CO}_{2}$ production by Inga vera embryos harvested in January 2010 in Piracicaba, SP, treated or not with carbendazin + thiram at a dose of $80 \mathrm{ml}$ of the commercial product for $100 \mathrm{~kg}$ of seeds, incubated at $7{ }^{\circ} \mathrm{C}$ for 15 days and at $25^{\circ} \mathrm{C}$ for four days (A), and at each 24-hour period for embryos incubated at $25^{\circ} \mathrm{C}$ for four days (B). The means followed by the same letter in normal font for $\mathrm{O}_{2}$ consumption and in italics for $\mathrm{CO}_{2}$ production, uppercase comparing chemical treatment, lowercase temperatures (A), uppercase comparing treatment with fungicide and lowercase incubation periods (B), do not differ by the Tukey test at $5 \%$ probability. 
Variations in the environment temperature constitute a factor of great influence in the respiratory rates to determine the speed of the enzymatic reactions that characterize the metabolism of the plants (Marenco \& Lopes, 2007).

Another fact that may have affected respiratory rates and germination (Figures $1 \mathrm{~A}$ and $\mathrm{B}, 3 \mathrm{~A}$ and $\mathrm{B}$ ) was the incidence of fungi in the embryos (Figure $2 \mathrm{~B}$ and $4 \mathrm{~B}$ ). This group of microorganisms plays a significant role in the post-harvest deterioration of the seeds classified as recalcitrant and of the intermediates (Berjak, 1995; Parisi et al., 2013).

The evident action of the fungicide only on the first respiration reading of the embryos incubated at $25{ }^{\circ} \mathrm{C}$ for four days in 2010 may indicate its low efficiency for periods longer than 24 hours (Figure 1B). Therefore, Fusarium oxysporum and Acremonium curvulum present in the embryos (Figure 2B) may have developed rapidly in the first hours, since they had favorable environmental conditions (temperature, humidity and substrate).

An important aspect verified for embryos incubated at both temperatures was the proximity of the mean $\mathrm{O}_{2}$ consumption and $\mathrm{CO}_{2}$ release values, with RQ near 1.0. These embryos present on average $57.6 \%$ of carbohydrates (Mello et al., 2010), which should be the main respiration substrate with complete oxidation occurring. In respiratory metabolism, RQ varies depending on the type of substrate that is oxidized (Marcos Filho, 2005; Marenco \& Lopes, 2007), being close to 1.0 for carbohydrates and 0.6 to 0.7 for fatty acids (Tcherkez et al., 2003). However, when the results of respiratory rates are analyzed in the first 72 hours at $25^{\circ} \mathrm{C}$, it is noted that the RQ was very low for the untreated seeds (Figure 1B), indicating that oxidative processes other than respiration were present.
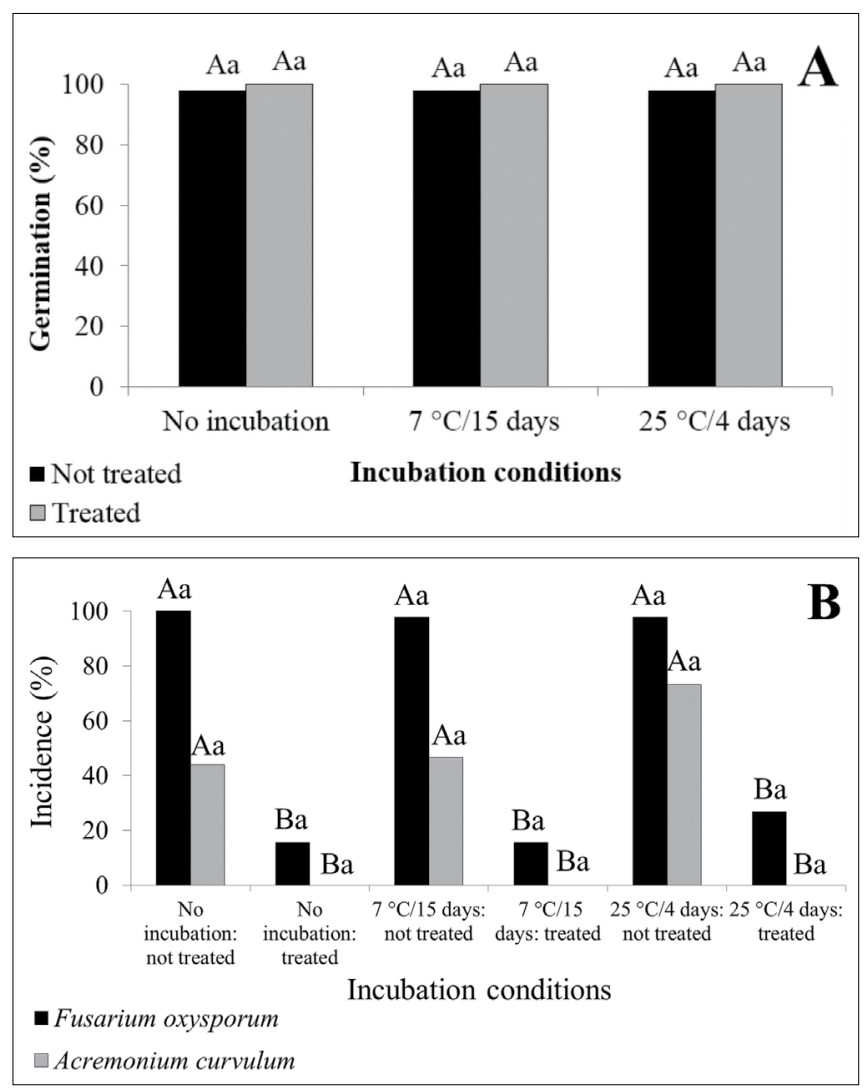

Figure 2. Germination (A) and incidence of fungi (B) detected in Inga vera embryos harvested in January 2010, Piracicaba, SP, treated or not with carbendazin + thiram at the dose of $80 \mathrm{ml}$ of the commercial product for $100 \mathrm{~kg}$ of seeds, before and after incubation at $7{ }^{\circ} \mathrm{C}$ for 15 days and at $25^{\circ} \mathrm{C}$ for four days. The means of germination and incidence of fungi followed by the same uppercase letters compare treatments with fungicide and lowercase incubation periods, they do not differ by the Tukey test at $5 \%$ probability. 

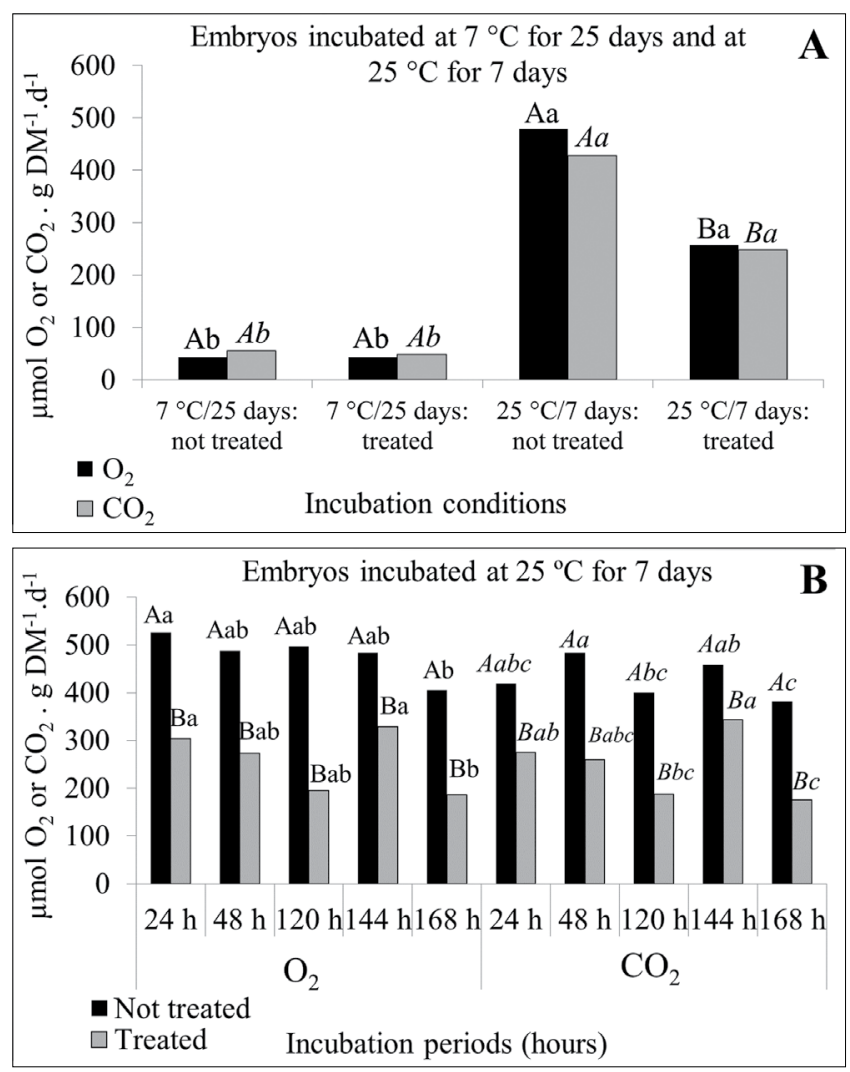

Figure 3. Average daily $\mathrm{O}_{2}$ consumption and average daily $\mathrm{CO}_{2}$ production by Inga vera embryos, harvested in January 2011, Piracicaba, SP, treated or not with carbendazin + thiram at a dose of $200 \mathrm{ml}$ of the commercial product for $100 \mathrm{~kg}$ of seeds, incubated at $7^{\circ} \mathrm{C}$ for 25 days and at $25^{\circ} \mathrm{C}$ for seven days (A) and at each 24 -hour period for embryos incubated at $25^{\circ} \mathrm{C}$ for seven days (B). The means followed by the same letter in normal font for $\mathrm{O}_{2}$ consumption and in italics for $\mathrm{CO}_{2}$ production, uppercase comparing chemical treatment, lowercase temperatures (A), uppercase comparing treatment with fungicide, and lowercase incubation periods (B) do not differ by the Tukey test at $5 \%$ probability.

In Caesalpinia echinata L. seeds, it was also found that the higher the temperature, the lower the RQ values, indicating oxidative processes that were probably related to the rapid deterioration of these seeds (Lamarca \& Barbedo, 2012). This fact did not occur when the embryos were treated with fungicide, and therefore the presence of fungi may be associated with an increase of oxidative processes, which may accelerate the deterioration of $I$. vera seeds.

Considering that fungicidal treatment was not necessary to improve germination of the 2010 embryos, which was already high (Figure 2A), but substantially reduced the incidence of F.oxysporum and A.curvulum (Figure 2B), the respiratory rates of the embryos of that year could suggest that the presence of fungi in the embryos does not alter the respiratory metabolism of these embryos. However, analyzing the daily incubation results at $25^{\circ} \mathrm{C}$ (Figure 1B), it was noted that the respiratory activity of these embryos is not homogeneous in the first days. Thus, it was verified that the fungicide action during the first 24 hours substantially reduced the respiratory rate of the embryos, indicating that the presence of fungi increases $\mathrm{O}_{2}$ consumption and $\mathrm{CO}_{2}$ release, which could be by the fungus respiration itself, by the increase in the respiration of the embryos in response to the presence of the fungi, or by both.

It was evident that the presence of fungi increases the respiratory rates of the embryo-fungus complex, which may represent an increase in the metabolism of the embryos. The fungi present in the untreated embryos incubated at $25^{\circ} \mathrm{C}$ for 4 hours must have developed rapidly since they found favorable conditions, thus increasing the respiratory rates of the embryos. 
The intense respiratory activity of the seeds, added to the activities of microorganisms, can cause the mass to warm up, further accelerating the deterioration process (Carneiro \& Aguiar, 1993).

In the following readings, there was a reduction in the respiratory rates of the untreated fungicide embryos, which could be attributed to the depletion of embryo reserves, to the increase in $\mathrm{CO}_{2}$ concentration and/ or reduction of $\mathrm{O}_{2}$ in the flask, or both. Meanwhile, there was an increase in respiratory rates up to 72 hours of incubation in the treated embryos, and then reduced. This may have occurred due to the loss in efficiency of the product, since the numerical value of the incidence of $F$. oxysporum increased with the incubation time (Figure 2B).

There are higher respiratory values for the 2011 embryos in comparing their rates with those of 2010 (Figures 1 and 3). Seed respiration rates are usually lower in the final stages of maturation, as verified in legume seeds such as soybean (Miller et al., 1983), brazilwood (Araujo \& Barbedo, 2017), and ironwood (Bragante et al., 2018). Therefore, it is probable that the embryos of 2011 with higher rates of respiration were at a maturation stage prior to 2010 . Germination values with or without fungicide treatment reinforce this idea (Figures $2 \mathrm{~A}$ and $4 \mathrm{~A}$ ).
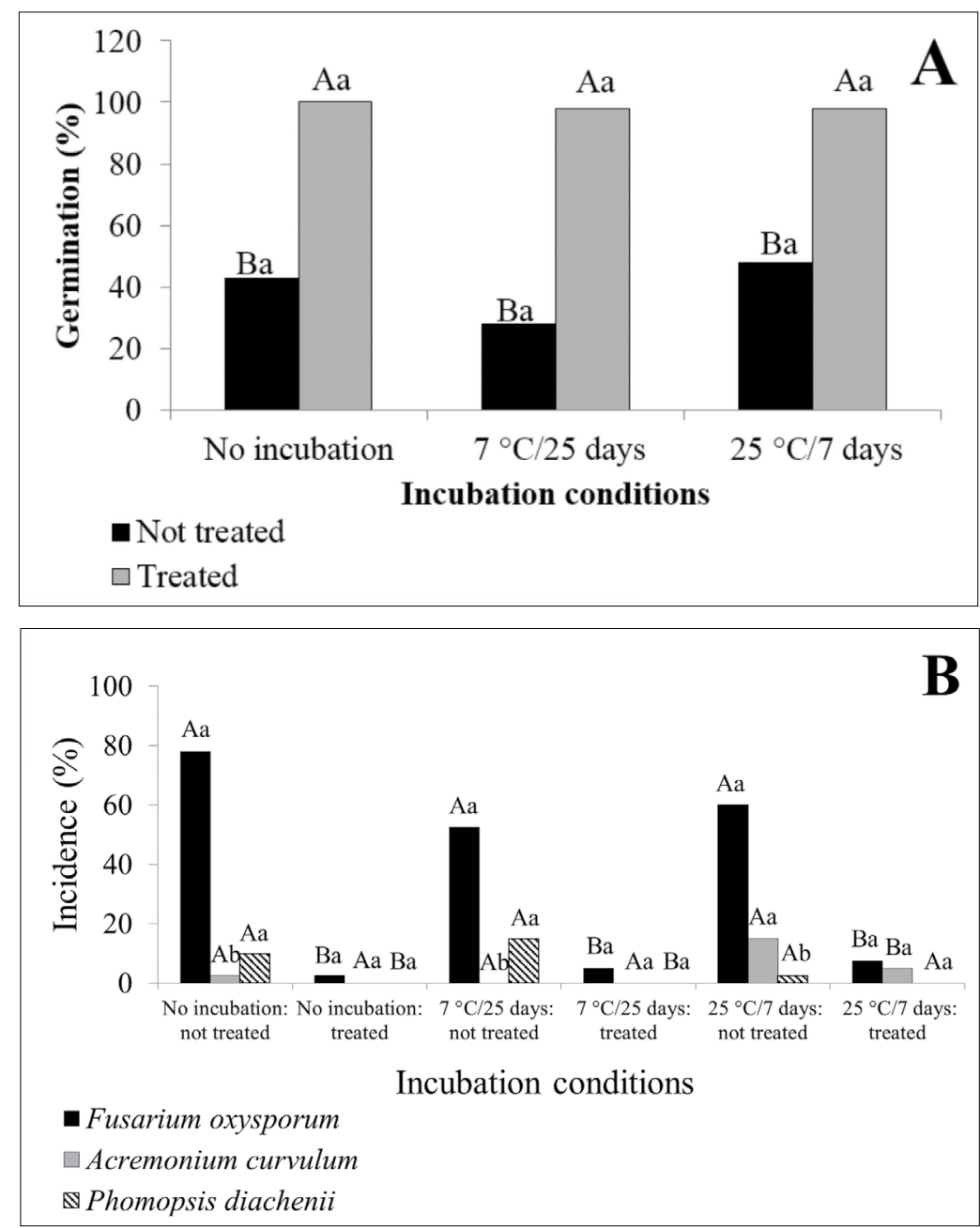

Figure 4. Germination (A) and incidence (B) of detected fungi in Inga vera embryos harvested in January 2011, Piracicaba, SP, treated or not with carbendazin + thiram at the dose of $200 \mathrm{ml}$ of the commercial product for $100 \mathrm{~kg}$ of seeds, before and after incubation at $7{ }^{\circ} \mathrm{C}$ for 25 days and at $25^{\circ} \mathrm{C}$ for seven days. Mean of germination and incidence of fungi followed by the same uppercase compare treatments with fungicide, and lowercase incubation periods, they do not differ by the Tukey test at $5 \%$ probability. 
The treatment with fungicide at the dose adopted in 2010 did not totally eliminate the F. oxysporum incidence in $I$. vera embryos, so that in order to control the inoculum in 2011 we opted for treatment with carbendazin + thiram in the dose of $200 \mathrm{ml}$ of the product to $100 \mathrm{~kg}$ of seeds. According to Parisi et. al. (2016), the same dose used was considered efficient in reducing the incidence of most of the fungi detected in I. vera seeds. In 2011, $\mathrm{O}_{2}$ consumption and $\mathrm{CO}_{2}$ release rates for $I$. vera embryos maintained at $7{ }^{\circ} \mathrm{C}$ (Figure $3 \mathrm{~A}$ ) again demonstrated that there were no differences in respiratory levels between treated and non-fungicidal embryos, even at a higher dose than in 2010, mainly due to the low metabolism of the embryos in this storage condition, independent of the F. oxysporum and Phomopsis diachenii fungi, which appeared to have a lower incidence in the incubated seeds (Figure 4B). According to Bonjovani \& Barbedo (2008), the temperature of $7{ }^{\circ} \mathrm{C}$ slightly lower than the basal temperature (that is, the minimum required for the germination process) is the most adequate for storing I. vera embryos.

The application of fungicide in the 2011 embryos controlled $P$. diachenii, but even at a higher dose than in 2010 it did not completely eliminate the incidence of F. oxysporum or A. curvulum (Figure 4B). Also, it was not as efficient in reducing respiratory rates of the embryos incubated at $25^{\circ} \mathrm{C}$, with values close to $500 \mu \mathrm{mol}$. $\mathrm{gDM}^{-1}$.day ${ }^{-1}$ to $400 \mu \mathrm{mol} . \mathrm{gDM}^{-1}$.day ${ }^{-1}$, respectively for $\mathrm{O}_{2}$ and $\mathrm{CO}_{2}$, for values close to $300 \mu \mathrm{mol} . \mathrm{gDM}^{-1}$.day ${ }^{-1}$ to $200 \mu \mathrm{mol} \mathrm{gDM}^{-1}$.day ${ }^{-1}$ (Figure $3 \mathrm{~B}$ ), as it was in the embryos of the previous year when they reached values close to $50 \mu$ mol.gDM $^{-1}$.day ${ }^{-1}$ (Figura $1 \mathrm{~B}$ ).

On the other hand, fungicide use reflected a significant increase in embryo germination (Figure 4A), even with higher respiratory rates (Figure $3 \mathrm{~A}$ and $\mathrm{B})$ than in the previous year (Figure $1 \mathrm{~A}$ and $\mathrm{B}$ ); but it is worth noting that the germination in 2010 was already close to $100 \%$ before application of the fungicide (Figure 2A), meaning that the embryos of 2011 were apparently more sensitive to the presence of fungi, again reinforcing the hypothesis of being more immature. It should be remembered that the fruits in both years were harvested at the time of their dispersal. Unlike in the orthodox seeds, the identification of physiological maturity in recalcitrant seeds is quite complex and difficult, because they do not have a characteristic cessation in metabolism between formation and germination (Barbedo \& Marcos Filho, 1998). Particularly in I. vera seeds, they can enter the germination phase even before their full development and dispersion, as demonstrated by Caccere et al. (2013). According Barbedo et. al. (2013), research should be directed to extending the maturing period of recalcitrant seeds, keeping them bound to the mother plant until the maturation process has been completed, or to a stage as close as possible to the point of physiological maturity. In this way, the damage caused by microorganisms could be more easily proven.

In spite of this difficulty, even though the fungicide action was not $100 \%$ efficient in the treated seeds, it enabled us to visualize the increase in respiratory rates of the embryo-fungus complex caused by both the respiration of the fungi present in the untreated seeds and by their action, intensifying their metabolism and thus affecting embryo conservation, not only from the destruction of their tissues, but also by the consumption of their reserves, and without correct targeting for germination. These results showed the importance of defining correct methodologies for measuring respiratory rates for each species, since the dynamics of the gases during the incubation period of embryos or seeds may not be uniform during the evaluation period.

In light of the results, new experiments could be conducted which reduce the time for the first gas reading and also the interval between readings. The use of products and doses which completely eliminate the initial inoculum of fungi in the embryos could also bring important contributions to the knowledge of the real fungi action on the respiratory rates of the embryos and their conservation.

\section{CONCLUSIONS}

The presence of fungi increases the respiratory rates of the embryo-fungus complex at measurable levels, demonstrably enhancing the metabolism and reducing the conservation of $I$. vera embryos.

The carbendazin + thiram treatment is efficient in reducing fungi associated to I. vera embryos and consequently the respiratory rates of the embryos, thus increasing the viability time of these embryos during storage. 


\section{SUBMISSION STATUS}

Submitted: 11 Oct., 2017

Accepted: 27 Nov., 2018

\section{CORRESPONDENCE TO}

\section{João José Dias Parisi}

Rodovia Luiz de Queiroz, km 149, CEP 02377-000, São Paulo, SP, Brasil

e-mail: joaoparisi2000@yahoo.com.br

\section{FINANCIAL SUPPORT}

We are thankful to Seeds Laboratory of the Instituto de Botânica of São Paulo, SP, for providing the necessary equipment for the realization of this study.

\section{REFERENCES}

Andréo Y, Nakagawa J, Barbedo CJ. Mobilização de água e conservação da viabilidade de embriões de sementes recalcitrantes de inga (Inga vera Willd. subsp. Affinis (DC.) T.D. Pennington). Revista Brasileira de Botânica 2006; 29(2): 309-318. 10.1590/S010084042006000200012

Araujo ACFB, Barbedo CJ. Changes in desiccation tolerance and respiratory rates of immature Caesalpinia echinata Lam. seeds. Journal of Seed Science 2017; 39(2): 123-132. 10.1590/2317-1545v39n2167788

Barbedo CJ, Centeno DC, Ribeiro RCLF. Do recalcitrant seeds really exist? Hoehnea 2013; 40(4): 583-593. 10.1590/ S2236-89062013000400001

Barbedo CJ, Marcos Filho J. Tolerância à dessecação em sementes. Acta Botanica Brasilica 1998; 12(2): 145-164. 10.1590/S0102-33061998000200005

Berjak P. The role of microorganisms in deterioration during storage of recalcitrant and intermediate seeds. In: Ouédraogo AS, Poulsen K, Stubsgaard F. Intermediate/ recalcitrant tropical forest tree seeds: proceedings of a working on improved methods for handling and storage of intermediate/recalcitrant tropical forest tree seeds. Rome: IPGRI; 1995. p. 121-126.

Berjak P, Cherian J, Makhathini AP, Sershen N, Pammenter NW. Embryonic axes of a tropical recalcitrant-seeded species day sand elimination of micro-organisms and potential for zygotic synthetic seed (synseed) production. Seed Science and Technology 2014; 42(2): 150-160. 10.15258/sst.2014.42.2.04

Bonjovani MR, Barbedo CJ. Sementes recalcitrantes: intolerantes a baixas temperaturas? Embriões recalcitrantes de Inga vera Willd. subsp. Affinis (DC.) T.D. Penn. toleram temperatura sub zero. Revista Brasileira de Botânica 2008; 31(2): 345-356. 10.1590/S0100-84042008000200017

Bonjovani MR, Barbedo CJ. Induction of tolerance to desiccation and to subzero temperatures in embryos of recalcitrant seeds of inga. Journal of Seed Science 2014; 36(4): 419-426. 10.1590/2317-1545v36n41027

Bragante RB, Hell AF, Silva JPN, Centeno DC, FigueiredoRibeiro RCL, Barbedo CJ. Physiological and metabolic responses of immature and mature seeds of Libidibia ferrea ((Mart. ex Tul.) L.P. Queiroz) under contrasting storage temperatures. Brazilian Journal of Botany 2018; 41(1): 43-55. 10.1007/s40415-018-0442-3

Brasil. Ministério da Agricultura, Pecuária e Abastecimento. Regras para análise de sementes. Brasília, DF: Mapa; 2009.

Caccere R, Teixeira SP, Centeno DC, Figueiredo-Ribeiro RCL, Braga MR. Metabolic and structural changes during early maturation of Inga vera seeds are consistent with the lack of a desiccation phase. Journal of Plant Physiology 2013; 170(9): 791-800. 10.1016/j.jplph.2013.01.002

Carneiro JGA, Aguiar IB. Armazenamento de sementes. In: Aguiar IB, Pinã-Rodrigues FCM, Figliola MB, editors. Sementes florestais tripicais. Brasília, DF: Abrates; 1993. p. 333-350.

Carvalho NM, Nakagawa, J. Sementes: ciência, tecnologia e produção. 4th ed. Jaboticabal: Funep; 2000.

Faria JMR. Desiccation tolerance and sensitivity in Medicago truncatula and Inga vera Willd. subsp. affinis (DC.) TD Penn. seeds [dissertation]. Wageningen: Wageningen University; 2006.

Ferreira DF. Sisvar: a computer statistical analysis system. Ciência e Agrotecnologia 2011; 35(6): 1039-1042. 10.1590/ S1413-70542011000600001

Kader AA, Saltveit ME. Respiration and gas exchange. In: Bartz JA, Brecht JK, Weichmann J. Postharvest physiology and pathology of vegetables. New York: Marcel Deckker; 2002. p. 7-29.

Lamarca EV, Barbedo CJ. Short storability of Caesalpinia echinata Lam. seeds as a consequence of oxidative processes. Hoehnea 2012; 39(4): 577-586. 10.1590/S223689062012000400006

Marcos Filho J. Fisiologia de sementes de plantas cultivadas. Piracicaba: Fealq; 2005.

Marenco RA, Lopes NF. Fisiologia vegetal fotossíntese, respiração, relações hídricas e nutrição mineral. Viçosa: Editora UFV; 2007.

Mello JIO, Barbedo CJ, Salatino A, Figueiredo-Ribeiro RCL. Reserve carbohydrates and lipids from the seeds of four tropical tree species with different sensitivity to desiccation. Brazilian Archives of Biology and Technology 2010; 53(4): 889-899. 10.1590/S1516-89132010000400019 
Miller MG, Leopold AC, Obendorf RL. Respiration during seed maturation. Physiolologia Plantarum 1983; 57(4): 397-401. 10.1111/j.1399-3054.1983.tb02758.x

Munsell Color. Munsell color charts for plant tissues. Baltimore: Munsell Color; 1952.

Oliveira CF, Oliveira DC, Parisi JJD, Barbedo CJ. Deterioração de sementes de espécies brasileiras de Eugenia em função da incidência e do controle de fungos. Revista Brasileira de Sementes 2011; 33(3): 520-532. 10.1590/S0101-31222011000300015

Pammenter NW, Berjak P. Physiology of desiccationsensitive (recalcitrant) seeds and the implications for cryopreservation. International Journal of Plant Sciences 2014; 175(1): 21-28. 10.1086/673302

Parisi JJD, Biagi DJ, Barbedo CJ, Medina PF. Viability of Inga vera Willd. subsp. affinis (DC.) TD Penn. embryos according to the maturation stage, fungal incidence, chemical treatment and storage. Journal of Seed Science 2013; 35(1): 70-76. 10.1590/S2317-15372013000100010

Parisi JJD, Biagi DJ, Barbedo CJ, Medina PF. Fungicide and drying effects on the viability of recalcitrant seeds of Inga vera Willd. subsp. affinis (DC.) TD Penn. Tropical Plant Pathology 2016; 41(3): 177-182. 10.1007/s40858-016-0084-6
Parisi JJD, Santos AF. Métodos convencionais de detecção de fungos em sementes. In: Santos AF, Parisi JJD, Menten JOM, editors. Patologia de sementes florestais. Colombo: Embrapa Florestas; 2011. p. 49-61.

Roberts EH. Predicting the storage life of seeds. Seed Science and Tecnology 1973; 1(4): 499-514.

Santana DG, Ranal MA. Análise da germinação: um enfoque estatístico. Brasília, DF: Editora UnB; 2004.

Santos AF, Parisi JJD, Menten JOM. Importância da sanidade das sementes florestais. In: Santos AF, Parisi JJD, Menten JOM, editors. Patologia de sementes florestais. Colombo: Embrapa Florestas; 2011. p. 11-13.

Tcherkez G, Nogués S, Bleton J, Cornic G, Badeck F, Ghashghaie J. Metabolic origin of carbon isotope composition of leaf dark-respired $\mathrm{CO}_{2}$ in French bean. Plant Physiology 2003; 131: 237-244. 10.1104/pp.013078

Vechiato MH, Parisi JJD. Importância da qualidade sanitária de sementes florestais na produção de mudas: divulgação técnica. Biológico 2013; 75(1): 27-32.

Walters C, Berjak P, Pammenter N, Kennedy K, Raven P. Preservation of recalcitrant seeds. Science 2013; 339(6122): 915-916. 10.1126/science.1230935 